\title{
Kierkegaard on the Value of Art: An Indirect Method of Communication
}

\author{
Antony Aumann \\ Northern Michigan University
}

\section{INTRODUCTION}

Questions about the value of art are nothing new. Lovers of art have been asked to explain its importance since the time of Plato's Republic. We encounter one common line of defence in Kierkegaard's writings. Like many $19^{\text {th }}$ century thinkers, including the leading figures of the Idealist and Romantic movements (Speight 2015; Zuckert 2010), Kierkegaard embraced a 'cognitivist' picture of the arts. He located art's value in its ability to teach or educate-to provide us with cognitive benefits.

Kierkegaard's version of cognitivism has a predictable existentialist twist. He is not as interested as Hegel or Schelling in whether art can express general truths about the spirit of the age. Nor is he as concerned as Kant with whether art manages to provide us with concrete representations of abstract ideas. Kierkegaard focuses his attention on art's ability to teach us about ourselves. Works of art matter to him because they can help us with the project of discovering who we are as individuals.

Despite cognitivism's popularity, it also received pushback in Kierkegaard's day. Some critics complained that what art accomplishes does not exactly amount to teaching. Others conceded that art might manage to teach in some sense, but they objected that it does not do so as well as philosophy or the sciences. The lessons communicated through art, they claimed, are never as clearcut or well-supported by reasons.

The goal of this chapter is to explain how Kierkegaard turns these objections on their heads. I will argue that he does so by making two moves. First, he maintains that works of art do not teach 'directly' by telling us truths and offering us evidence. Instead, art educates in an 'indirect' fashion by helping us make our own discoveries. Second, the fact that art does not teach in a straightforward manner is not a defect. On the contrary, it is precisely because art teaches indirectly that it teaches better than philosophy and the sciences.

\section{PHILOSOPHICAL OBJECTIONS TO COGNITIVISM}

To appreciate Kierkegaard's contributions to the cognitivist tradition, we must set them against the backdrop of two well-known challenges. The first challenge is the 'no assertions' objection. It states that, on a traditional view, educating people involves giving them truths they need to know. The problem with most works of art is that they do not try to impart any truths. They do not even make any claims or assertions about the way the world goes. Thus, they cannot be said to teach in the traditional sense.

The second major challenge to the cognitivist view of art is the 'no reasons' objection. It points out that teaching is more than offering people truths. Real teaching requires providing people with knowledge. People have knowledge only when they have justifications for what they take to be 
true. Thus, the deeper problem with works of art is that, even when they do convey truths, they often fail to support them with justifications-i.e. reasons, arguments, or evidence.

These two objections have received much attention in contemporary aesthetics. But they are not peculiar to our times. Their pedigree extends back to Plato's argument in the Republic for thinking art should be banished from the ideal city. They also stand behind the view held by many philosophers in the modern era that art is not as reliable a path to the truth as science (Carroll 2003, pp. 368-369; Kivy 1997, pp. 84-119). Finally, we catch glimpses of the two objections in the reasoning presented by Hegel for his 'end of art' thesis. Despite the educational function art has served throughout history, Hegel claimed, it ultimately must be replaced by philosophy. For philosophy is a more transparent medium for communicating truths (Hegel 1975, pp. 10-11; see Beiser 2005, pp. 286-297; Pattison 1992, pp. 14-16).

It should not surprise us, therefore, that Kierkegaard alludes to the two objections in his writings. At times he even does so sympathetically. Sylvia Walsh (1994, pp. 170-173) calls attention to passages in Either/Or, Concluding Unscientific Postscript, and Works of Love that characterize art as a deficient teacher, one that fails to present the world as it actually is. Elsewhere Kierkegaard describes a passion for art as a preoccupation with a realm other than our own; it is a flight from reality into fantasy (SUD, 77-78 / SKS 11, 191; CUP, 1.387-390 / SKS 7, 352-356). In his most critical moments, he appears to agree with Plato: 'the poet is, in a godly sense, the most dangerous of all' (TM, 225 / SKS 13, 281). Such passages lead Kai Hammermeister to conclude 'Kierkegaard associates the aesthetic more or less with deception and corruption' (2002, p. 130).

\section{KIERKEGAARD'S COGNITIVISM ABOUT THE ARTS}

Kierkegaard's negative comments about art should not unduly colour our interpretation. For he usually restricts them to particular kinds of art or specific approaches to art. When we take a holistic look at his writings on the subject, it becomes apparent that he has a positive conception of the role art can play in human life. As noted at the outset, we can think of Kierkegaard as falling in line with the Idealists and Romantics on this issue. However much he disagrees with them elsewhere, he shares their view of the importance of art. He too believes art matters because it has the power to educate us about the world and ourselves.

Hints of Kierkegaard's cognitivist view of the arts appear in his account of Thomasine Gyllembourg's first novel, A Story of Everyday Life. He praises the book because it reveals the way life actually is. It offers readers 'an explanation of life or a strengthening of their understanding of it' (TA, 22 / SKS 8, 25). To some it is even 'a guide' (TA, 22 / SKS 8, 25). Kierkegaard's cognitivism also comes across in what Ettore Rocca (1999) describes as his call for a 'second aesthetics' in which poets express new ideals for living (JP, 2.288-289 / SKS 24, 82-83 ; see also McDonald 2014, p. 26). Kierkegaard's clearest statements on the value of art, however, occur in the context of his defence of his own attempts at literature. He turns to a literary or poetic format because he considers it the best way to help readers learn. Indeed, when it comes to ethics and religion, good instruction has to be artistic (CUP, 1.79, 242-243 / SKS 7, 29, 220-221; PV, 43, 54 / SKS 16, 25-26, 35; PC, 94, 123, 133-144 / SKS 12, 103, 128-129, 137-147; see Aumann 2010). Thus, in the mind of Kierkegaard, 
the Hegelians have it backwards. Art rather than philosophy or science is the superior way to educate people.

Kierkegaard is an important member of the cognitivist tradition for several reasons. Chief among them is that his version of cognitivism contains a couple of insights that allow him to avoid the objections just described. His first insight is that philosophers often presuppose a narrow view of teaching. They tend to assume that teaching involves imparting truths and supporting these truths with reasons. To use Kierkegaard's terminology, when philosophers talk about teaching, they restrict their focus to the 'communication of knowledge' or 'direct communication.'

If the 'direct' model of teaching were the only one, the standard objections to cognitivism would go through. Art would be an impoverished educator because it seldom follows the 'truth plus justification' pattern. But, and this is Kierkegaard's second insight, the direct model is not the only legitimate model. It may reflect the stereotypical way instruction occurs in philosophy or the ideal pursued in the sciences, but it does not capture how instruction happens in art. When works of art teach, they tend to do so indirectly rather than directly. They educate us without asserting truths or offering reasons to believe them.

Kierkegaard's writings contain several accounts of art's indirect method of instruction or what he calls 'indirect communication' (JP, 1.267-293 / SKS 27, 390-434; CUP, 1.72-80, 242-299 / SKS 7, 73-80, 220-273; PC, 123-144 / SKS 12, 128-147; PV, 41-56 / SKS 16, 23-36). The details of these accounts differ, but the central idea remains the same. Rather than straightforwardly telling us the truth, art indirectly teaches us by empowering us to uncover the truth for ourselves. It provides us with the tools, training, and background resources we need to make discoveries on our own. For this reason, Kierkegaard describes indirect communication as 'the communication of capability' rather than 'the communication of knowledge' (JP, 1.281-290 / SKS 27, 404-414). The implication here is that the indirect method does not involve giving people new information to know. Instead, it involves helping people cultivate the ability to learn new things on their own. The aim, as Kierkegaard puts it, is to help the learner 'stand alone' (JP, 1.280 / SKS 27, 403; WL, 274-270 / SKS 9, 272-273).

To further explain indirect communication, Kierkegaard draws on Socrates's metaphor of midwifery or 'maieutics' (PV, 7-9 / SKS 13, 13-15; CUP, 1.80 / SKS 7, 80; JP, 1.274-280 / SKS 27, 397-403; see also Aumann 2010, pp. 297-305; Daise 1999). The maieutic teacher does not give birth to his or her own knowledge and then pass it along to the learner. He or she rather helps learners 'give birth' to their own knowledge just as the midwife draws the infant from the mother. More perspicuously, the maieutic teacher induces learners to arrive at the relevant lesson on their own rather than straightforwardly telling it to them.

One qualification to this picture deserves our attention. Although Kierkegaard often associates art with indirect communication, he does not identify the two (CUP, 1.251-300 / 7, 228273; see Aumann 2008, pp. 30-57, 2010). He does not reduce art to indirect communication or indirect communication to art. It is possible, he says, to teach indirectly without using artistic means. One prominent example comes from Socrates. His question-asking method counts as indirect communication even though it does not amount to fine art (CUP, 1.277-278 / SKS 7, 251-254). For it too prompts learners to reason under their own steam to a conclusion rather than handing it over 
to them as a finished product. In addition, Kierkegaard claims that some works of art attempt to teach us directly rather than indirectly. They are didactic by nature, sometimes even beating us over the head with their theses and badgering us into accepting their points of view (see TA, 34-35, 41 / SKS 8, 34-35, 41). Finally, Kierkegaard acknowledges that many artworks do not teach us at all. Some attempt to assist us with the learning process but fail; the tools, training, or resources they offer us are flawed. Other works of art do not even try to help us. They serve as diversions from the task of learning rather than occasions to pursue it. Works of these last two sorts are among the targets of Kierkegaard's negative remarks about art mentioned above.

\section{ARTISTIC METHODS OF INDIRECT COMMUNICATION}

There are a number of specific ways in which art teaches us indirectly, according to Kierkegaard. Chief among them is by providing us with cognitive tools we can use to enhance our understanding of our lives. In particular, works of art help us by offering us lenses' through which to see ourselves better or prisms through which to view the world around us afresh. These lenses or prisms can focus our attention on considerations we have overlooked. They also have the power to structure our conception of the world in ways we could not have imagined on our own.

Kierkegaard's way of expressing the point is to say works of art can serve as 'mirrors' for

ourselves (FSE, 25-26, 40-44 / SKS 13, 53-54, 66-70; see Stokes 2009, pp. 111-133). He is most explicit about this way of framing the idea when it comes to his own literary writings. Indeed, as the motto for one of his books, he uses the saying 'Such works are mirrors: when an ape looks in, no apostle can look out' (SLW 8 / SKS 6, 16). Kierkegaard's idea here is that, if we attend carefully to the stories he gives us, we can see reflections of ourselves in the characters they describe.

Works of art that serve the kind of mirroring function Kierkegaard has in mind may not themselves contain much knowledge. The standard philosophical objections may be right that they offer us little in the way of truth-plus-justification. Thus, Kierkegaard admits in his journals that in many cases of indirect communication 'there is no object' or 'the object drops out' (JP, 1.270-271 / SKS 27, 395). What he means here is that there is no piece of knowledge or bit of information conveyed from teacher to learner. Nevertheless, works of art that serve a mirroring function still have cognitive value because we can use them to acquire knowledge about the world and ourselves. In fact, like ordinary mirrors, they may enable us to discover things we would otherwise miss. They may reflect back to us truths about ourselves we are too myopic to see on our own.

\section{ART AS MIRROR OF THE SELF}

Kierkegaard's idea that works of art can serve as mirrors for ourselves is a fruitful one. Although not always owing to his influence, it is also one that has received attention in contemporary aesthetics (e.g. Danto 1981). Perhaps the most lucid account of the art-as-mirror-of-the-self view occurs in the work of Elisabeth Camp. It is worth taking a moment to explain her view.

Camp (2009) distinguishes between two ways we can see ourselves in the characters we encounter in works of literature. The first, called 'pretense,' involves using our imaginations to transform ourselves into the figures being described. When reading Tolstoy's Anna Karenina, for example, I engage in pretense if I contemplate what it would be like to live in Anna's shoes. I 
mentally pull myself out of my own situation and put myself into hers. In the most radical version of this exercise, I strip off all my character traits_everything that makes me who I am. I replace them with the traits Tolstoy has given Anna. I attempt to think, feel and experience the world exactly as she does.

Camp's second way of seeing ourselves in literary characters is 'metaphorical seeing-as.' It brings us closer to the idea Kierkegaard has in mind. Instead of putting myself in Anna's shoes so I can understand her life, I use Tolstoy's description of Anna to help me understand my own life. Her story becomes a pattern for structuring and organizing my own. I come to see my troubles in terms of her troubles and my choices in terms of her choices. As a result, my image of myself becomes 'transfigured,' to use Arthur Danto's word. I gain a new picture of who I am. New aspects of my identity come to the forefront and new connections between moments in my life solidify. It may become apparent, for example, that like Anna I too can be driven to fits of jealousy when my goals are threatened, or that I too have pursued romantic love to the detriment of my own well-being.

\subsection{DAVID AND BATHSHEBA}

Kierkegaard provides us with several of his own examples of metaphorical seeing-as. One of the most revealing occurs in For Self-Examination, where we find his rendition of the story of David and Bathsheba (FSE, 37-39 / SKS 13, 64-65). The outlines of the story are well-known. Although King David has many wives, he becomes smitten by the beautiful Bathsheba, who is herself already married to another. Unable to resist her charms, David has Bathsheba brought to the palace so he can sleep with her. As part of the cover up for his adultery, he arranges for Bathsheba's husband, Uriah, to be moved to the front lines of a battle where the fighting is fierce and he is soon killed.

God sends the prophet Nathan to help David see the error of his ways. But rather than coming right out and admonishing David, Nathan offers him a parable. It is a tale about a rich man who must prepare a meal for a traveller. In a fit of selfishness, the rich man decides to forgo slaughtering any of his own many animals for the feast. Instead he seizes his poor neighbour's one and only ewe lamb, whom the neighbour has loved and treated like a daughter.

On Kierkegaard's re-telling of the Biblical account, David becomes enamoured with Nathan's tale. He praises its literary richness and offers Nathan advice about how to make it more interesting. But then Nathan utters the famous words - 'thou art the man' — and David's perspective shifts. He suddenly sees himself as the metaphorical target of the parable. The rich man's actions and his callous insensitivity to how his greed harms the less fortunate become a lens through which David sees himself. They focus his attention on his own selfishness with Bathsheba and his own insensitivity to the suffering of Uriah. With his sins in view, David repents.

\subsection{BEYOND LITERATURE}

Kierkegaard, like Camp, focuses on literature when making his case for the cognitive value of art. He is less sanguine about other types of art. Following a $19^{\text {th }}$ century trend, his comments about the revelatory powers of painting and sculpture in particular are negative (EO 1, 49-57 / SKS 2, 57-65; EO 2, 133-139 / SKS 3, 132-137; see Fried 2002, pp. 141-166; James 2008). But I believe it is a mistake on Kierkegaard's part to downplay the power of painting and sculpture. They too can 
provide us with lenses or prisms that help us restructure our vision of ourselves. They too can work as mirrors that reflect back transfigured images of our lives-images that afford us new ways to conceive of who we are.

Consider one of Caravaggio's final paintings, The Denial of Saint Peter (1610). It depicts a scene found in all four gospels from the last day of Jesus's life. After Jesus is betrayed and arrested, Peter follows him into the courtyard of the high priest. Over the course of the evening, three people accuse Peter of belonging to Jesus's group of disciples. Peter denies the charge each time. He thereby fulfils Jesus's prophesy that he would be denied thrice before the cock crowed.

In The Denial of Saint Peter, Caravaggio paints one of the accusations. He has close-cropped three figures - an indicting servant girl, an inquiring soldier whom the girl has summoned, and Peter himself - so each appears at half-length. The light is cast so that the girl and the soldier are in the dark. We barely see the questioning finger of the soldier or the two pointing fingers of the servant girl. Instead, Caravaggio highlights Peter's indignant scowl along with his hands, which he has folded inward toward his chest as if to say, 'Who me?'

The power of the painting lies in its ability to communicate more than just Peter's physical appearance. As explained by Keith Christiansen (2017), the curator of the exhibit at the Metropolitan Museum of Art in New York where the painting hangs, Caravaggio 'probes with unparalleled poignancy a dark world burdened by guilt and doom.' He has rendered Peter's outward visage in such a way that it provides a window into his inner mental state. We see in Peter's defiant facial expression an anticipation of his coming remorse.

When we contemplate Peter's emotional state, our mirror neurons fire, leading us to empathize with his distress. The terror-cum-regret that overcame him washes over us as well. These powerful emotional tremors pave the way for associated memories. We find ourselves thinking of moments when we too have denied the ones we love in order to save ourselves. In this way, Caravaggio sheds light not only on the life of Saint Peter but on our lives as well. His painting works as a mirror that reflects back on us viewers the truth about who we are. Thus, we discover in Peter's denial of Jesus our own failings, just as David saw his failings in the sins of the rich man from Nathan's parable.

\section{ART, SCIENCE, AND PHILOSOPHY}

I have been expanding on Kierkegaard's cognitivist view of the arts. In particular, I have been elaborating on what he means when he says that art teaches us indirectly rather than directly. But there is another feature of Kierkegaard's view that deserves attention. He does not merely maintain that art's mode of instruction is different than the one we typically find in philosophy and the sciences. He also holds that art's mode of instruction is better.

Kierkegaard here inverts another popular line of thinking. Many philosophers have held that insofar as art teaches at all it does so in a deficient manner. It would be better if artists were more straightforward about their lessons - if they came right out and told us what we needed to know and gave us clear reasons for why we should believe them. Indeed, this is why Hegel held that the messages communicated in works of art ultimately need to be clarified and justified by philosophy and the sciences. Kierkegaard's insight is that Hegel and likeminded thinkers have it backward. Art 
is not held back by its indirect method of instruction but is better because of it. Art's indirectness, in other words, is not a defect but a virtue. It is something that makes art's mode of instruction superior to that provided by philosophy and the sciences.

Kierkegaard provides several defences of this claim (see Aumann 2010; Tietjen 2013, pp. 49-60). One of the most prominent is that art's indirect approach is pedagogically superior to more direct approaches. It is simply a more effective way to help people learn. Kierkegaard's argument here revolves around two claims. First, an indirect method of teaching is better than a direct method because it requires learners to become more actively engaged in the learning process. In line with contemporary educational theory, Kierkegaard maintains that a lesson is more likely to hit home and stick with people when they have to discover it for themselves than when it is handed to them. In Kierkegaard's language, learners are less likely to end up with 'rote understanding' this way (PV, 41-55 / SKS 16, 23-36; CUP, 1.72-80, 277-78 / SKS 7, 72-80, 251-254; TDIO, 37-38 / SKS 5, 416).

Second, although there are several ways to undertake the indirect method of instruction, artistic ways are often the best. The reason is that artistic instruction is more responsive to our nature as human beings (PV, 54 / SKS 16, 35). In particular, it better accommodates the fact that we are not computers or robots who process ideas in a strictly logical way. Our passions, emotions, and imaginations all play roles in our decision making processes. The value of art over philosophy and the sciences is that it has the ability to engage us on all these levels. Art addresses 'the whole person,' as the popular phrase has it. Appreciating the force of this claim requires a detour through Kierkegaard's account of human nature.

\section{KIERKEGAARD ON HUMAN NATURE}

The centrepiece of Kierkegaard's view of human nature is that we are not purely rational creatures. Proof of this claim lies in the kind of errors we commit. If we were purely rational, Kierkegaard avers, incoming information would always perfectly translate into action and belief (CUP, 1.22 / SKS 7, 30; SUD, 92-96 / SKS 11, 205-208). We would always do what we took to be good and always believe what appeared to us to be true. Thus, any mistakes would be the result of a lack of education. We would do evil only because we did not yet know what the good really was. So too, we would believe falsehoods only because we had not yet been taught what was actually true. All sin, to put the point how Anti-Climacus does, would be a matter of ignorance (SUD, 95 / SKS 11, 207).

But this is not how things go. Our problem as human beings is not always a lack of knowledge or education (CUP, 1.242, 249-50 / SKS 7, 220, 226-227). We sometimes fail to do what we take to be right or intentionally do what we know is wrong (SUD, 90 / SKS 11, 203; TDIO, 100 / SKS 5, 467; see Kosch 2006, pp. 170-171). In addition, we find ourselves believing what deep down we are aware is false or failing to believe what in a sense we recognize is correct. These possibilities-weakness of the will, radical evil, and self-deception-all show that we are not purely rational creatures. Other faculties play a role in our decision-making and belief-forming processes. 


\subsection{PASSION}

To be a human being, for Kierkegaard, is also to be a passionate being (TA, 61-69 / SKS 8, 59-66; CUP, 1.33, 130-131, 311 / SKS 7, 39, 122-123, 283-284; see Evans 2009, pp. 21-22; Walsh 1994, pp. 200-202). In other words, a genuinely human existence is one that involves caring about things. It is a matter of taking things to be of significance and regarding them as worth structuring our life around. We are passionate in the relevant sense, Johannes Climacus says, if we are willing to take risks for things, venture for them, or pursue them at great cost to ourselves (CUP 200-204 / SKS 7, 183-186).

To say we are passionate beings is not to say we are all already properly passionate. The problem with many of us is that we do not have enough passion. Indeed, Kierkegaard often complains that his age is a tepid one (TA, 68 / SKS 8, 66). 'What our age needs is pathos,' he writes in his journals, 'just as scurvy needs green vegetables' (JP, 3.428 / SKS 20, 119). Climacus goes so far as to say that most people have forgotten what it is to be passionate and thus have forgotten what it is to be human (CUP, 1.242 / SKS 7, 220).

Contrary to some readings (e.g. Dreyfus 1999), Kierkegaard does not recommend that we be passionate about just any old thing. Although he does suggest caring about something is better than caring about nothing, he believes the object of our cares matters (CUP, 1.201 / SKS 7, 184; JP, 3.427 / SKS 18, 217). For instance, he laments that some people place too much emphasis on abstract reflection (CUP, 249 / SKS 7, 226-227). He chastises others for being preoccupied with mundane worldly affairs (SUD, 48 / SKS 11, 163; CD, 124 / SKS 10, 135). Perhaps Kierkegaard's favourite whipping boy, however, is the person who obsess over what 'the crowd' thinks, something he believes ought not to concern us at all (PV, 106-112 / SKS 16, 86-92; UDVS, 95-96 / 8, 199200).

In Kierkegaard's mind, what we ought to care about are ethical and religious matters. We ought to devote ourselves to doing the good, loving our neighbour, and abiding by God's will (UDVS, 24-30 / SKS 8, 139-148; WL, 44-60 / SKS 9, 51-67). Relatedly, we should care about developing our identities in an ethical and religious direction. We should focus our attention on the goal of becoming ideal versions of ourselves (CUP, 1.130 / SKS 7, 122; EO 2, 178 / SKS 3, 173174; see Stokes 2009, pp. 63-64).

\subsection{EMOTION}

Kierkegaard does not just advocate for the importance of passion in the sense of care or devotion. He also regards passion in the sense of emotion or feeling as a crucial component of human nature (Furtak 2005, pp. 45-51; Strelis 2013; Evans 2009, p. 113). In fact, one of the mistakes Kierkegaard harps upon is the attempt to bracket our emotions from our inquiries (CUP, 1.32-34, 350-351 / SKS 7, 38-40, 320-321). Under the sway of the Platonic tradition, he thinks we often attempt to approach issues from a dispassionate point of view (CUP, 1.253 / SKS 7, 230). In part this means we try not to let our own personal interests and agendas—our 'passions' in the first sense of the terminterfere with our judgments about what is right or true. But it also means we try to keep our emotions out of it. We aim to think and reason with an even-keeled or placid disposition. 
Kierkegaard has two problems with our pursuit of this sort of objectivity. First, he maintains that being completely dispassionate and disinterested is impossible. We never approach anything with perfect neutrality. Indeed, it is a fundamental feature of human consciousness that we are always in some way 'interested' in the issues we think about (JC, 170 / SKS 15, 57; see Stokes 2009, pp. 47-60). We always approach them against the backdrop of pre-existing concerns and so we always possess a variety of emotional attitudes toward them (EO 2, 164 / SKS 3, 161; see Ferreira 1991, pp. 125-127).

Second, Kierkegaard believes that to the degree it is possible to become dispassionate, doing so is often a mistake. As Rick Furtak (2005, pp. 48-50, 2008, pp. 59-66) has shown, Kierkegaard embraces a perceptual theory of the emotions according to which our emotions can help us see the world better. They can serve as lenses that focus our attention. In particular, they can put in sharp relief the value or significance of what we encounter. Kierkegaard goes so far as to say that 'fundamentally all understanding depends upon how one is disposed toward something' (JP, 4.354 / SKS 23, 24-25). As such, 'a person's inner being...determines what he discovers and what he hides’ (EUD, 60 / SKS 5, 70).

\subsection{IMAGINATION}

One final faculty Kierkegaard discusses is the imagination. He identifies it as our ability to see possibilities or make images of possibilities (SUD, 31 / SKS 11, 147; see Frances 2014; Grøn 2002). Of particular importance for Kierkegaard is the role the imagination plays in helping us come up with possible ways to live. Included under this umbrella is possible ways we can think, reason, feel, and care. Thus, our imagination shapes and delimits what we can do with all our faculties. It is 'the capacity instar omnium [for all capacities]' (SUD, 31 / SKS 11, 147). As we read in Sickness Unto Death, 'When all is said and done, whatever of feeling, knowing, and willing a person has depends upon what imagination he has' (SUD, 31 / SKS 11, 147).

Kierkegaard's respect for the power of imagination leads him to worry about its misuse (Söderquist 2016, p. xiv; Stokes 2009, p. 75). For instance, Anti-Climacus notes with consternation how many of us get caught up in fantasies about ourselves. We let ourselves be seduced by stories about who we are that are loftier (or lower) than the facts allow. Those of us who succumb to such illusions are said to suffer from 'the despair of infinitude' (SUD, 30-33 / SKS 11, 146-148). This phrase is meant to capture the idea that we have failed to ground our identity in the finite realm of the actual world.

Just as often, however, Kierkegaard thinks we err on the opposite side. We go astray not because of an excess of imagination but because of a lack of imagination. In the most troubling case, we become small-minded about our own possibilities (SUD, 33-35 / SKS 11, 149-151). We wrongly restrict our sense of what we can do with our lives to what society tells us. We confine our vision of whom we might become to the options the media or the public deems acceptable. As a result, we fail to pursue paths that might be more appropriate for us as unique individuals. 


\section{THE PEDAGOGICAL SUPERIORITY OF ART}

With Kierkegaard's view of human nature in hand, we are in position to appreciate his argument for the pedagogical superiority of art. His guiding insight, once again, is that teachers ought to use a mode of instruction that is responsive to our nature as human beings. He concedes that if we were purely rational creatures, it might be appropriate to engage us on an entirely rational level (PV, 5354 / SKS 16, 35). It might be fitting to adhere to the ideal of direct communication and offer us only theses and justifications. For we could be counted on to transform this information into right action and right belief. As it happens, though, we are not purely rational creatures. Passion, emotion, and imagination also play important roles in our decision making and belief-forming processes. Therefore, we need a mode of instruction that engages us on all these levels as well.

It is here that fine art comes into play. Works of art are powerful educators, for Kierkegaard, because they do not engage us only on a rational level. They help us to imagine what it would be like to occupy perspectives other than our own, as we see with Tolstoy's Anna Karenina. Works of art also evoke powerful emotions in us and these emotions focus and refine our view of the world. They disclose aspects of it we would miss if we remained dispassionate. Moreover, because art conveys ideas in an emotional medium, these ideas become embedded in our minds. They sink in more deeply than they would if they had been conveyed prosaically. This is why Caravaggio's painting, The Denial of Saint Peter, has such staying power. The vision of life it affords lingers in our minds because it reaches us on an affective level. Finally, because art engages our imaginations and emotions, it also moves our passions. The parable Nathan offers David shows how, more effectively than the street corner evangelist's harangues, art can make us care in new ways about new things (PV, 41-53 / SKS 16, 23-36; BA, 16 / SKS 15, 101-102; see Aumann 2010, pp. 317-324).

We can now see why Kierkegaard regards Hegel's view as backwards when it comes to art. The very features of art that led Hegel to say it was an ineffective guide compared to philosophy and science are what make it so potent in Kierkegaard's mind. Art's engagement with our passions and emotions is not a reason to be suspicious of its ability to teach us. Quite the opposite. It is precisely why art is the superior mode of instruction.

\section{RELATED TOPICS}

Kierkegaardian Pseudonymity and the Impossibility of Written Communication (Joseph Westfall); Nature and Natural Beauty (Anthony Rudd); Anthropology and the Self from Kant to Kierkegaard (Roe Fremstedal); Critical Theory and Kierkegaard's Communicative Strategy for Undermining Ideology (Shoni Rancher)

\section{FURTHER READING}

Jothen, P 2014, Kierkegaard, aesthetics, and selfhood: the art of subjectivity, Ashgate, New York.

This text presents Kierkegaard's views on aesthetics through the lens of his religious and especially his Christian commitments.

Pattison, G 1992, Kierkegaard: the Aesthetic and the Religious: From the Magic Theatre to the Crucifixion of the Image, Springer. 
A seminal analysis of Kierkegaard's views on art that helpfully situates them against the historical backdrop of Romantic and Idealist aesthetics.

Söderquist, AS 2016, Kierkegaard on Dialogical Education: Vulnerable Freedom, Lexington Books, Lanham, MD.

This monograph traces the role art plays for Kierkegaard in encouraging the exercise of our freedom, placing special emphasis on the power of stories to help us shape ourselves.

Walsh, S 1994, Living Poetically: Kierkegaard's Existential Aesthetics, Penn State Press, University Park, PA.

An influential study of the aesthetic dimensions of selfhood in Kierkegaard's writings, in particular exploring the sense in which identity-formation is poetic for Kierkegaard.

Westfall, J 2007, The Kierkegaardian Author: Authorship and Performance in Kierkegaard's Literary and Dramatic Criticism, DeGruyter, Berlin.

This book unpacks Kierkegaard's aesthetics by providing detailed commentaries on his often-neglected works of literary and dramatic criticism.

\section{REFERENCES}

Aumann, A 2008, Kierkegaard on the Need for Indirect Communication (Ph.D. Dissertation). Indiana University, Bloomington, IN.

Aumann, A 2010, 'Kierkegaard on Indirect Communication, the Crowd, and a Monstrous Illusion', in RL Perkins (ed), The Point of View, International Kierkegaard Commentary, Mercer University Press, Macon, GA, pp. 295-324.

Beiser, FC 2005, Hegel, Routledge, New York.

Camp, E 2009, 'Two Varieties of Literary Imagination: Metaphor, Fiction, and Thought Experiments', Midwest Studies in Philosophy, vol. 33, no. 1, pp. 107-130.

Carroll, N 2003, 'Aesthetics and the Educative Powers of Art', in R Curren (ed), A Companion to the Philosophy of Education, Blackwell, Oxford, UK, pp. 365-383.

Christiansen, K 2017, 'The Denial of Saint Peter', Exhibition Catalogue: Metropolitan Museum of Art, retrieved September 12, 2017, from $<$ http://www.metmuseum.org/art/collection/search/437986>.

Daise, B 1999, Kierkegaard's Socratic Art, Mercer University Press, Macon, GA.

Danto, AC 1981, The Transfiguration of the Commonplace: A Philosophy of Art, Harvard University Press, Cambridge, MA.

Dreyfus, HL 1999, 'Kierkegaard on the Internet: Anonymity vs. Commitment in the Present Age', Kierkegaard Studies: Yearbook, pp. 96-109.

Evans, CS 2009, Kierkegaard: An Introduction, Cambridge University Press.

Ferreira, MJ 1991, Transforming Vision: Imagination and Will in Kierkegaardian Faith, Oxford University Press, Oxford. 
Frances, M-B 2014, 'Imagination', in SM Emmanuel, J Stewart, \& W McDonald (eds), Kierkegaard's Concepts: Tome III: Envy to Incognito, Kierkegaard Research: Sources, Reception and Resources, Ashgate.

Fried, M 2002, Menzel's Realism: Art and Embodiment in Nineteenth-century Berlin, Yale University Press, New Haven, CT.

Furtak, RA 2005, Wisdom in Love: Kierkegaard and the Ancient Quest for Emotional Integrity, University of Notre Dame Press.

Furtak, RA 2008, 'Love and the Discipline of Philosophy', in EF Mooney (ed), Ethics, Love, and Faith in Kierkegaard, Indiana University Press, Bloomington, IN, pp. 59-71.

Furtak, RA 2015, 'Love as the Ultimate Ground of Practical Reason: Kierkegaard, Frankfurt, and the Conditions of Affective Experience', in A Rudd \& JJ Davenport (eds), Love, Reason, and Will: Kierkegaard After Frankfurt, Bloomsbury, New York, pp. 217-242.

Grøn, A 2002, 'Imagination and subjectivity', Ars Disputandi, vol. 2, no. 1, pp. 89-98.

Hammermeister, K 2002, The German aesthetic tradition, Cambridge University Press, Cambridge, UK. Hegel, GWF 1975, Aesthetics: Lectures on Fine Art, Oxford University Press, New York.

James, D 2008, 'The significance of Kierkegaard's interpretation of Don Giovanni in relation to Hegel's philosophy of art', British Journal for the History of Philosophy, vol. 16, no. 1, pp. 147162.

Kivy, P 1997, Philosophies of Arts: An Essay in Differences, Cambridge University Press, Cambridge.

Kosch, M 2006, Freedom and Reason in Kant, Schelling, and Kierkegaard, Oxford University Press, Oxford.

McDonald, W 2014, 'Aesthetic/Aesthetics', in SM Emmanuel, J Stewart, \& W McDonald (eds), Kierkegaard's Concepts: Tome I: Absolute to Church, Kierkegaard Research: Sources, Reception and Resources, Ashgate.

Pattison, G 1992, Kierkegaard: the Aesthetic and the Religious: From the Magic Theatre to the Crucifixion of the Image, Springer.

Rocca, E 1999, 'Kierkegaard's Second Aesthetics', in NJ Cappelørn \& H Deuser (eds), Kierkegaard Studies. Yearbook, DeGruyter, Berlin, pp. 278-292.

Söderquist, AS 2016, Kierkegaard on Dialogical Education: Vulnerable Freedom, Lexington Books, Lanham, MD.

Speight, A 2015, 'Philosophy of Literature in the Nineteenth Century', in N Carroll \& J Gibson (eds), Routledge Companion to Philosophy of Literature, pp. 30-39.

Stokes, P 2009, Kierkegaard's Mirrors: Interest, Self and Moral Vision, Palgrave Macmillan, New York.

Strelis, A 2013, 'The Intimacy between Reason and Emotion: Kierkegaard's "Simultaneity of Factors", Res Philosophica, vol. 90, no. 4, pp. 461-480.

Tietjen, MA 2013, Kierkegaard, Communication, and Virtue: Authorship as Edification, Indiana University Press, Bloomington, IN.

Walsh, S 1994, Living Poetically: Kierkegaard's Existential Aesthetics, Penn State Press, University Park, PA.

Zuckert, R 2010, 'The Aesthetics of Schelling and Hegel', in D Moyar (ed), The Routledge Companion to Nineteenth Century Philosophy, Routledge, New York, pp. 165-193. 
Pre-publication draft: Please cite the version published by Routledge in The Kierkegaardian Mind. 